of Cambridge, UK, followed by research work there in J. J. Thomson's Cavendish Laboratory on the eve of the First World War. During this period, Lawrence and his father drew on work by Max von Laue and others to develop the theory and technique of X-ray diffraction. Their pioneering research on crystal structures, and thereby the Nobel prize, followed. Neither Bragg travelled to Stockholm to collect their prize as both were involved in war research: William worked on submarine detection, Lawrence on sound ranging. They were the lucky ones; Robert Bragg died at Gallipoli in 1915.

The crystallography work is the climax of Jenkin's detailed account of the Braggs' early careers. The bulk of William and Lawrence Bragg, Father and Son focuses on the family's life in Australia. Jenkin, himself from Adelaide, has assiduously mined Australian and British archives and gives us a wonderfully rich picture of the Braggs in Adelaide - a useful corrective to later UK-centred accounts. Although only one of the 19 chapters is devoted to the prizewinning collaboration, Jenkin draws on unpublished material to throw some new light on this work.

Despite a slight tendency to romanticize the Braggs, Jenkin deals effectively with the difficulties of being on the geographical margins of a research community and of establishing credibility from a position of intellectual isolation. Brief comparisons with analogous academics working in other fields might have added a broader sense of perspective here. He also opens for debate the issue of relations between father and son over the allocation of credit for $\mathrm{X}$-ray crystallography. Lawrence seems to have felt unjustly treated, and professional and social contacts with his father were often fraught. Again, a comparative study - on the atomic physicists J. J. Thomson and his son George Paget Thomson, for example - might have helped us to get a better sense of the validity of Jenkin's argument.

In 1915, William accepted the professorship of physics at University College, London, from where he hoped to play a more prominent part in national scientific administration. In 1923, he became director of the Royal Institution. There, he oversaw the growth of X-ray crystallographic research and what is now called public engagement until his death in 1942 . He was one of the most prominent spokesmen for science in the interwar period, and president of the Royal Society between 1935 and 1940.

Notwithstanding its early brilliance, most of Lawrence's career came after the events described in the book. In 1919, he succeeded Rutherford as professor of physics at the University of Manchester, UK, and created his own research school to study the X-ray crystallography of inorganic molecules. After a brief period as director of the National Physical Laboratory, UK, he again followed Rutherford to become head of the Cavendish Laboratory. There, he encouraged the efflorescence of molecular biology, which led to the elaboration of the structure of DNA in 1953.

Given all this, and his emphasis on the father-son relationship, it is a pity that Jenkin squeezes the entirety of the Braggs' post-1920 careers into two short chapters, and that he chooses to use his brief epilogue to quarrel with Hunter's recent interpretation of Lawrence's relationships with his parents. Perhaps there is scope for a follow-up volume dealing more fully with the Braggs' later careers and the elaboration of Jenkin's views of the darker side of this 'extraordinary collaboration'.

Jeff Hughes is senior lecturer at the Centre for the History of Science, Technology and Medicine, University of Manchester, Manchester M13 9PL, UK. He is author of The Manhattan Project: Big Science and the Atom Bomb.

\title{
Climate change for the masses
}

\section{The Hot Topic \\ By Gabrielle Walker and David King \\ Bloomsbury: 2008. 309 pp. $€ 9.99$ \\ Harvest Books: 2008. 288 pp. $\$ 14.00$}

\section{David S. Reay}

Two years ago, I wrote in these pages about the need for a book on climate change that could engage millions, equivalent to the forcefulness and accessibility of Rachel Carson's classic Silent Spring. Since that time, the Stern Review, the Fourth Assessment Report from the Intergovernmental Panel on Climate Change and Al Gore's An Inconvenient Truth have joined the groaning shelves of works about global warming. Public awareness of climate change is soaring, and political parties increasingly vie for the greenest ground. So do we really need yet another mass-market climate-change book? When it is this good, unequivocally yes.

Misinformation and unsupported statements abound on both sides of the debate. Myriad shades of green advice on planet-friendly living compete for our attention with end-is-nigh hyperbole and diatribes from climate sceptics. The Hot Topic has an authoritative clarity that scythes through the junk science and brushes aside the brigades of doom-mongers and overly earnest environmentalists.

Its authors - geophysics writer and broadcaster Gabrielle Walker and ex-UK-government science adviser David King - have chosen a simple format. They guide the reader systematically through the history of climate science, the projections and uncertainties, the solutions and politics. After an engaging discussion of the greenhouse effect and its discovery, taking in key players such as Joseph Fourier and John Tyndall, they examine the palaeological record and the evidence for human-induced changes in climate.

So far, so unremarkable. These topics are the bread-and-butter of books on climate change and many readers will be familiar with the content. Similarly, the brief chapter on climatechange effects is covered in much more depth in Mark Lynas's recent book Six Degrees. It is when Walker and King get into the solutions and politics of climate change that their book really begins to show its pedigree.

First the authors ask: can we actually avoid a $2{ }^{\circ} \mathrm{C}$ rise in average global temperature - in other words, dangerous climate change? They think it unlikely, but stress that this figure isn't an all-or-nothing doomsday trigger, and that it is still possible to stabilize greenhousegas concentrations in the atmosphere at a level that should avoid the most catastrophic impacts. On how to achieve this, their message is loud and clear: only a concerted global effort that makes use of new and established tools will do.

Walker and King give short thrift to geoengineering proposals, such as injecting clouds of sulphur dioxide into the atmosphere, labelling them dangerous tinkerings that trade one kind of pollution for another. Instead, they draw together an impressive and upbeat portfolio of possible efficiency boosters, renewable energy sources and emerging technologies, such as carbon capture and storage.

They advocate feeding more nuclear power into this mix, urging the reader to consider the arguments carefully. They contend that a new generation of more efficient nuclear power plants would create much less waste, adding just $10 \%$ to existing UK levels. But for a country that is already home to 100,000 tonnes of radioactive waste, this additional material would prompt a hefty rise in the cost of longterm storage. Their positive view of the nuclear option also fails to square with their justified scepticism over the pollution-swapping risks of geoengineering.

On climate economics and policy, Walker's writing skills and King's first-hand knowledge make for an informative and accessible package. Their empowering approach leaves no room for despair or inaction. A section on personal solutions necessarily goes over ground that will be familiar to most readers, but adds to the inspirational tone. In truth, I have never enjoyed reading a book on climate change more. The balance of accessible writing and peer-reviewed science - including a myth-busting appendix - should put a skip in the step of even the most jaded climatologist. The search for a climate-change equivalent of Silent Spring is over.

David S. Reay is a Natural Environment Research Council Fellow in the School of GeoSciences, University of Edinburgh, Crew Building, West Mains Road, Edinburgh EH9 3JN, UK. He is author of Climate Change Begins at Home. 